\title{
Technology, innovation and knowledge: The importance of ideas and international connectivity
}

\author{
Ulf Andersson ${ }^{\mathrm{a}, \mathrm{b}}$, Àngels Dasí ${ }^{\mathrm{c}}$, Ram Mudambi ${ }^{\mathrm{d}, *}$, Torben Pedersen ${ }^{\mathrm{e}}$ \\ a Malärdalen Unversity, School of Business, Society and Engineering, Box 883, SE-721 23 Västerås, Sweden \\ ${ }^{\mathrm{b}}$ BI Norwegian School of Business, Department of Strategy, N-0442 Oslo, Norway \\ ${ }^{\mathrm{c}}$ University of Valencia, Faculty of Economics, Avd. Tarongers, s/n, 46022 Valencia, Spain \\ ${ }^{\mathrm{d}}$ Temple University, Fox School of Business, PA 19122 Philadelphia, USA \\ e Bocconi University, Department of Management and Technology, Via Röntgen, 1, 20136 Milan, Italy
}

\section{A R T I C L E I N F O}

\section{Article history:}

Available online 13 September 2015

\section{Keywords:}

Technology

Innovation

Knowledge

Sourcing

Internal transfer

External transfer

Integration

\begin{abstract}
A B S T R A C T
The relevance of ideas is at the core of the IB field and has been captured in concepts like technology, innovation and knowledge. While these concepts have evolved over the last decades, the point that the ideas and the international connectivity are central for IB remains genuine. This paper is an attempt to take stock of the evolution of the concepts technology, innovation and knowledge in IB literature along the past five decades with a particular focus on the role of the Columbia Journal of World Business (CJWB) and the Journal of World Business (JWB) in this evolution. Likewise, our objective is to offer a research agenda for the coming decade. We proceed in two steps. First, we scrutinize how the IB literature has progressed and expanded over the last five decades, illustrating this on the basis of articles published in CJWB and JWB. Second, we take a helicopter view on this literature and reflect on the insights we have gained and the challenges the IB field has ahead that can constitute the basis for a future research agenda. We highlight the importance of creating a micro-foundation of knowledge processes where mechanisms on the interaction between the higher levels (nation, firm, teams) and the individual level are clarified.
\end{abstract}

(C) 2015 Elsevier Inc. All rights reserved.

\section{Introduction}

The importance of ideas and creativity in value creation processes is dramatically increasing and they are at the heart of business. Investments in human capital, machinery and infrastructure are all very important ingredients, but it is the ideas of where and how to use them that are key to the development and growth of businesses. The global context with its diverse knowledge pools and clusters provides both valuable sources for new knowledge and also outlets for leveraging innovation when selling the new outputs in a wide range of markets.

Over the years the importance of ideas for international business (IB) has been captured in different concepts like technology, innovation and knowledge. The focal concepts have evolved over time, but the key point that the ideas are central for IB remains as sincere as ever. In fact, the possession and internalization of intangibles in the form of ownership advantages constitutes

\footnotetext{
* Corresponding author.

E-mail addresses: ulf.r.andersson@mdh.se (U. Andersson), angels.dasi@uv.es (À. Dasí),ram.mudambi@temple.edu (R. Mudambi), torben.pedersen@unibocconi.it (T. Pedersen).
}

the main explanation for the existence of multinationals (e.g. Buckley \& Casson, 1976; Dunning, 1993). Morck and Yeung (1991) demonstrated that only multinationals with substantial R\&D and marketing intangibles were valued at a premium over purely domestic firms. Recent estimates demonstrate that well over three quarters of the value of publicly traded firms can be traced to intangibles (Mudambi, 2008).

Much has been written about technology, innovation and knowledge in an international context. Certainly, the literature has matured to a point where we have seen numerous review papers and meta-analyses on these issues (e.g. Alavi \& Leidner, 2001; Wijk, Jansen, \& Lyles, 2008; Michailova \& Mustaffa, 2012). This paper is an attempt to take stock of what we in the IB scholarly community know about ideas and creativity, the role of Journal of World Business (JWB) in this literature and to offer a research agenda for the coming decade. With this aim, we document the development of these issues in the IB literature mainly on the basis of articles published in JWB, and then we will reflect on insights from the vast literature and point at areas for future research.

Technology, Innovation and Knowledge are three related phenomena and concepts that have been at the core of the worldwide economy evolution and the international business 
growth during the last fifty years. Technology refers to the tools and machines that are used to solve real-world problems. Innovation is a new idea, a more effective device or process. Knowledge is the familiarity with or understanding of something such as facts, information or skills.

A striking example of the power of these phenomena is Malcolm P. Mclean's idea (dating back to the 1950s) of transporting entire truck-trailers (containers) without unloading the cargo when switching the mode of transportation e.g. from train to ship. This idea turned out to be one of the most powerful innovations, promoting containerization and the inter-modal cargo transport, which has been a major driver of globalization through the lowering of logistics and transport costs. ${ }^{1}$ In this example the development of the container reflects the technology, the idea of inter-modal cargo transport is the innovation and the knowledge is represented by Malcolm P. Mclean's substantial previous experience in the transport sector.

IB scholarship has developed along two contextual levels when dealing with these three concepts. At one level, in what might be called "macro-IB", there is the study of aggregate levels of business activity at the inter-country and even inter-regional level (where by regions we refer to groups of countries). This level of IB research is mainly developed on the foundations of international trade theory. A useful organizing framework for innovation and knowledge at this level is the national systems of innovation (NSI) approach (Lundvall, 2007) that has provided an explanation about the location advantages for firms as well as about the effect that foreign direct investment (FDI) spillovers have on the host countries.

At another level, in what might be called "micro-IB", there is the study of international activities of firms. The most important firms for study at this level of IB research are multinational enterprises (MNEs). This level of research developed by applying insights mainly derived from industrial organization economics (Buckley \& Casson, 1976). Beginning with the work of Kogut and Zander (1993), an even larger literature has mushroomed, studying MNEs' innovation and knowledge management, as they tap into diverse pockets of knowledge around the world in order to buttress their competitive advantages.

We want here to highlight two key aspects - the more external interaction between the firm and the location and the internal interaction between the firm and the lower levels of teams and individuals - that have affected these two levels of analysis and shaped the importance of innovation, knowledge and technology for IB literature. The firm is conceptualized as the agent that combines the external exposure (in terms of adapting, positioning, sourcing, leveraging ideas) with the internal mobilization (in terms of creation, integration and dissemination of ideas). This conceptualization points at the MNE's role of orchestrating both the interaction with the location and the interaction with individuals in the MNE.

\subsection{Interaction between the firm and the locations}

Both the macro-IB and the micro-IB studies are engaged with the interaction between the firm and the international environment (Dunning, 1993; Rugman \& Verbeke, 2001). Within this literature, the mobile firm specific advantages (carried by MNEs) and immobile location bound advantages (attached to the locations) must evolve together in order to create value. A

\footnotetext{
${ }^{1}$ Some decades ago Peter Drucker pointed out that “...there was not much new technology involved in the idea of moving a truck body off its wheels and onto a cargo vessel... but... without it, the tremendous expansion of world trade in the last forty years - the fastest growth in any major economic activity ever recorded, could not possibly have taken place."
}

traditional view on location would imply that location bound advantages are generic resources available to all firms in the particular location (Dunning, 1993). However, more recent research challenges this view by suggesting that MNEs differ in their location capability ("sense of place"). This implies that not all MNEs are equally good at making the most of the location bound advantages in a given location (Zaheer \& Nachum, 2011).

An integral part of this literature that relates to ideas and creativity is the explicit recognition of the ongoing progression of "fine-slicing" (Mudambi, 2008). Creative activities are being constantly honed and separated into more narrowly defined "specialized" (non-repetitive) activities, with the remainder becoming "standardized" and repetitive. Continual innovation results in persistent activity down-skilling and de-skilling: components of activities that were once creative become standardized, modularized and amenable to being offshored to low-cost, low-skill locations or being automated. There is a concomitant process of "value migration", i.e., as specialized activities are down-skilled and become standardized, value becomes concentrated with the activity slices that remain nonrepetitive. In other words, the creative "heart" of an activity becomes more narrowly defined (Contractor, Kumar, Kundu, \& Pedersen, 2010).

This more narrow definition has both a cost and a capability aspect. High knowledge activities are expensive, so defining them more narrowly reduces costs. However, more specialization also increases innovation and customization capabilities. Related to this process of "fine-slicing" is the configuration of the firm's activities. The MNE's activities are arranged in such a way that they make the most of the geographic dispersion by constructing a global network. MNEs can thereby access dispersed pools of knowledge fostering their innovation. Consequently, by interacting with locations MNEs have the possibility to organize their activities for balancing the exploitation of their current knowledge base and the exploration of new knowledge bases (Cantwell \& Mudambi, 2005; Cantwell \& Mudambi, 2011).

\subsection{Interaction between the firm and the individuals}

Orchestration of the multinational firm relies heavily on connectivity: inter- and intra-organizational networks as well as between and within locations. Connectivity appears in two forms organization-based "pipelines" created and maintained by MNEs and individual-based personal relationships that often arise within communities of practice, networks or global diasporas (Lorenzen \& Mudambi, 2013). While the key role of connectivity, has been recognized in the IB literature the bulk of the research has focused on the organizational level of analysis, i.e., intra-MNE knowledge flows (Foss \& Pedersen, 2004) and MNE knowledge sourcing in clusters and global centers of excellence (Cantwell \& Mudambi, 2011). The point we make here highlights the importance of individual actors in determining outcomes. MNEs, communities of practice and networks provide respectively formal and informal operating frameworks within which individual employees undertake innovative activities.

The foregoing discussion highlights two important themes for future developments in IB research. First, recognizing the importance of the individual level of analysis enables us to distinguish between the ability to undertake knowledge-centric actions that further the interests of the organization (e.g., the MNE) and the willingness to do so (Mudambi, Pedersen, \& Andersson, 2014). This ability-willingness divide and more generally the microfoundations of the knowledge processes have received relatively little attention in the IB literature thus far (Foss \& Pedersen, 2004) as the prime focus has been on knowledge sharing on organizational level. Even the limited lower level literature is 
rather scattered under a variety of different labels ranging from attention (Bouquet \& Birkinshaw, 2008) to power (Mudambi \& Navarra, 2004). Therefore, more focus on lower levels of analysis and their subsequent aggregation can help in understanding the mechanisms underlying organizational processes. Since individuals are the real agents in knowledge processes an understanding of higher level knowledge processes must be based on an understanding of the individual level.

Second, the importance of connectivity and the relevance of individual actors suggest that the boundary spanning literature offers a fruitful avenue along which IB research can develop new insights (Carlile, 2002). Connectivity creates the conditions for softening some of the problems that arise when transferring knowledge, but boundary spanning recognizes that for such connectivity to be fruitful it also requires overcoming resistance of various forms (Schotter \& Beamish, 2010).

The literature on ideas and creativity has developed considerable both in terms of theoretical sophistication and methodological depth, however, we highlight that a major challenge ahead of us is the development of theories and methodologies that allow us to study knowledge as a multilevel construct (with interactions between the relevant levels) and where the (higher level) organizational constructs are grounded at the (lower) individual level.

We take stock of the extant pool of knowledge in two steps. First, we will scrutinize how the IB-literature has progressed and expanded over the last five decades. In particular, we examine how the key concepts and topics that have been highlighted in the literature have changed significantly along this period. In the main, we illustrate this on the basis of articles published in JWB and as such we will reveal the significant role played by the journal in the IB literature. Second, we take a helicopter view on the vast literature produced over the last five decades and reflect on the insights we have gained and the challenges we have ahead of us. This will enable us to identify where we should focus our attention in future research on sourcing, generating, applying and leveraging ideas in the international context.

\section{Technology, innovation and knowledge in Journal of World Business: an analysis of five decades of research}

The last five decades of history have witnessed major technological changes and innovations that have fueled global trade and the evolution of international firms but also that have raised important issues as the relevance of knowledge processes for sustaining firms' competitive advantage.

With the aim of studying thoroughly the overall trajectory of these concepts during this period we have done a literature review of the journal that shows that JWB and its predecessor Columbia Journal of World Business (CJWB) have been in continuous dialog with the environmental changes as well as with the evolution of the IB field.

We undertook a Boolean search of all the articles published in JWB and CJWB since their inception, ${ }^{2}$ including those articles that had the following words in their titles: knowledge, innovation or technology. This search resulted in a preliminary list of 118 articles with the following distribution by key word (see Table 1 ).

After eliminating duplications (articles having two or more of the key words in the title) we obtained a list of 110 articles that had at least one of the key words in the title. We analyzed the abstract of these articles and eliminated those that were not related to our approach. This process ended in a final list of 82 articles $^{3}$ that

\footnotetext{
2 The Boolean search was done in September 2nd, 2014.

3 The articles that appear in Figure 1, but are not explicitly cited in text are indicated in the reference list with a ${ }^{*}$ mark.
}

Table 1

Number of articles by key words in the title in JWB and CJWB.

\begin{tabular}{lc}
\hline Word in the title & Number of articles \\
\hline Knowledge & 34 \\
Innovation & 24 \\
Technology & 60 \\
Total & $\mathbf{1 1 8}$ \\
\hline
\end{tabular}

present the following description regarding the year of publication and the main word in the title ${ }^{4}$ (see Fig. 1).

Concerning the evolution of the main themes, it is striking that technology-related issues centered the attention of authors during the first two decades of the journal, while innovation appeared as a key word in the eighties and knowledge surfaced as the most relevant concept during the last decade. These trends are comparable to those shown in the similar time period by other relevant journals in the IB field such as the Journal of International Business Studies (Fig. 2). The evolution depicted here reflects not only how IB scholars have treated these main issues but also portrays the main questions international firms and institutions have been concerned with during the last 50 years.

It is fair to say that the focus has been on ideas and creativity in the whole period, but the concepts for capturing their essence have changed. This is true not only for the IB-field, but also for the broader field of strategy and management. One way to illustrate the development in the key concepts is to use the analogy of a tree, where the technology, innovation and knowledge are like the leaves, branches and trunk of the tree, respectively. The technology is the tangible outcome of ideas and creativity, while the innovations are those that form the platforms for development in technology (like the branches that carry the leaves), and the knowledge is composed by the intangible and tangible elements that are underlying both innovations and technology (like the trunk that is feeding the branches and the leaves). Part of the trunk is hidden under the ground such like tacit knowledge that is also considered to be the most valuable for supporting both the innovations and the technology. This analogy tells us that the last 50 years of research in this area have been a journey of digging deeper and conceptualizing the underlying factors. It is also a reflection of the global development where technology cycles are getting faster and imitation is becoming quicker, which forces firms to focus more on higher level knowledge and capabilities in order to create value. The management of knowledge including the processes of sourcing, integration and transfer of knowledge across the MNE has become the key in staying ahead of competition.

When comparing Figs. 1 and 2 it is noteworthy that CJWB/JWB picked up articles on technology and innovation relatively early (even before JIBS). However, it was relatively late in featuring articles on knowledge processes, with its first articles appearing in 2002 while the first articles on such processes appeared in JIBS in 1993. This was due to the disciplinary domain of CJWB, which saw itself as more of an international political economy journal (in the middle ground between Foreign Policy and Harvard Business Review). This editorial perspective was a better fit with the literature on technology and innovation that was more macrooriented. It was not until the editors Fred Luthans and John Slocum took over in 1996 that it turned into a more management oriented journal. In their first editorial note the two editors stated "Our stated vision for JWB is to contribute to three of the most important areas of global management-strategy, human resources and

\footnotetext{
${ }^{4}$ Articles with more than one key word in the title were assigned to the most relevant key word.
} 


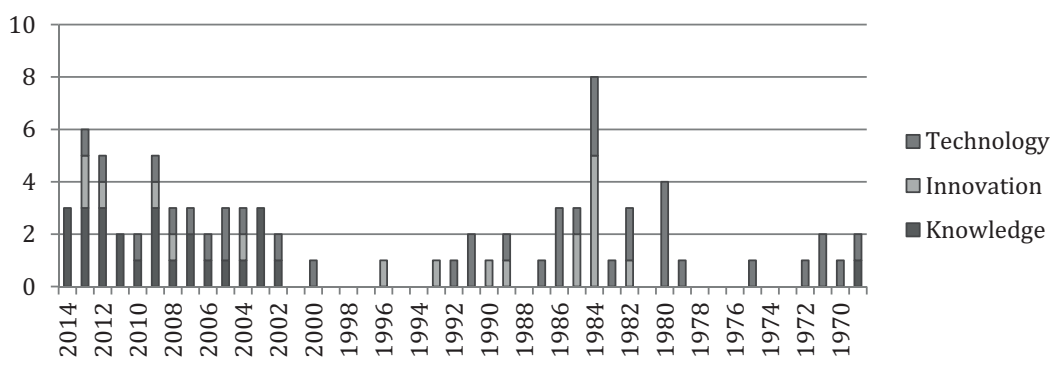

Fig. 1. Articles distribution by year and key word in CJWB and JWB 1965-2014.

marketing" (Luthans \& Slocum, 1997, p. 2). This was a significant shift in the profile, but it still took some years before JWB was able to catch up, since the journal missed the first wave of literature on knowledge processes fueled by authors like Rob Grant, Bruce Kogut, and Udo Zander. Knowledge management is mentioned for the first time in 2000, in the editorial note as the editors emphasize "we would hope that advanced information technology, knowledge management, and entrepreneurship in the international arena will also be reflected in future issues" (Luthans \& Slocum, 2000, p. 331-332).

In further analyzing the evolution of the JWB we have advanced in two steps: first we performed a general overview of the listed articles, and second we identified the main contributions of the journal in this time period by scrutinizing the most relevant articles in the list.

\subsection{General overview of JWB and CJWB (1965-2014)}

With the aim of understanding which are the main concepts and constructs related to knowledge, innovation and technology that have appeared over the years, we did a content analysis of the articles' abstracts. We inspected the abstracts separately, codified, and classified the main concepts.

To accomplish this classification we employed Eisenhardt and Santos (2001) categorization of knowledge processes as consisting of four specific sub-processes: external transfer, sourcing, internal transfer, and integration. From a theoretical point of view this categorization augments our understanding as it allows us to take into account the nuances of the firm's interactions both internally and externally, and how the main perspective - macro or micro has evolved over the years. We also applied this categorization of knowledge processes to the concepts of technology and innovation, as this is consistent with the way IB literature has considered them. Mainly as sources of sustained advantage and superior performance, and therefore given much attention to those elements that distinguish and affect the different sub-processes.

The four categories of knowledge-processes reflect two fundamental underlying phenomena: the exploitation of the extant competencies of the corporate group (home-base exploitation) and the creation of competencies that are new to the group (home-base augmenting) (Kuemmerle, 1999; Cantwell \& Mudambi, 2005).

The processes of external and internal knowledge transfer are competence exploiting as they essentially include the transfer of existing knowledge from the home country or another important country to subsidiaries (internal transfer) or external counterparts (external transfer in the foreign country). Sourcing and integration are, on the other hand, more about acquiring new knowledge from outside the MNE and integrating it in the organization and therefore essentially about creating competencies that are new to the corporate group. The four knowledge processes can further be divided into whether they are mainly taking place within or outside the boundaries of the firm. Applying these two dimensions the four knowledge sub-processes can be placed in a two-by-two table as illustrated in Table 2.

\subsection{Main contributions of the JWB to the role of technology, innovation and knowledge}

We have identified the most relevant articles in JWB and CJWB by using Google Scholar citations. Among our previous list of 82 articles, we have selected those whose total citations were above the average (average citations per article is 38.8). In order to be up to date we have also added a few articles, dealing with relevant new issues related to the here analyzed processes, that have been published more recently (in 2012-2014) and that in our minds have the potential to reach a high number of citations. All in all this is resulting in 30 articles that are listed in Table 3.

This general overview reveals some interesting insights related to the evolution of the main research questions. Clearly, while the dominant perspective of the first two decades had been more on international exploitation of existing competencies of the group (home-based exploiting knowledge processes), mainly centered on how MNEs can protect their technology investments when doing business abroad, subsequent development of the journal has diverted into the global sourcing and creation of competencies that

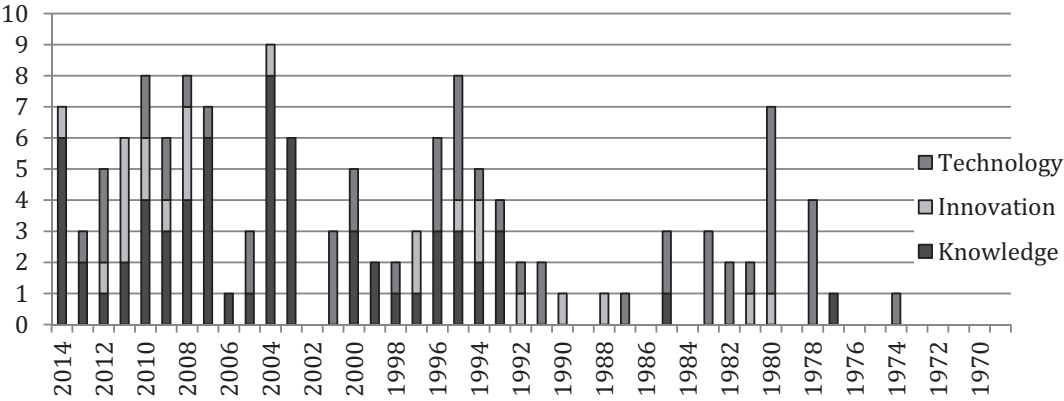

Fig. 2. Articles distribution by year and key word in JIBS 1969-2014. 
Table 2

The four knowledge sub-processes.

\begin{tabular}{lll}
\hline & $\begin{array}{l}\text { Competence } \\
\text { exploitation }\end{array}$ & $\begin{array}{l}\text { Competence } \\
\text { creation }\end{array}$ \\
\hline $\begin{array}{l}\text { Outside the firm boundaries } \\
\text { Within the firm boundaries }\end{array}$ & $\begin{array}{l}\text { External transfer } \\
\text { Internal transfer }\end{array}$ & $\begin{array}{l}\text { Sourcing } \\
\text { Integration }\end{array}$ \\
\hline
\end{tabular}

are new to the group (home-based augmenting knowledge processes) with more attention on internal processes and factors. Additionally, we can see how the journal has evolved from being mainly focused on the interaction of the firm with the environment toward the analysis of the firm's internal processes related to knowledge, innovation and technology. In this way, initial articles were mainly concerned with the external transfer and sourcing processes, where the research questions were analyzed at the country, industry and firm level. However, as the field has evolved toward paying more attention to the role of the firms and individuals in managing the links across the boundaries, the journal has also switched focus toward more micro levels of analysis and has made relevant contributions regarding internal transfer and integration processes.

Some other reflections that cut across the listed articles are that qualitative articles were more dominant in the beginning of the period, when it was difficult to get access to data on these knowledge processes. However, quantitative analysis are dominating in the more recent articles, indicating that data availability has much improved both when it comes to primary data (e.g. survey) and secondary data (e.g. patents and trademarks). Also the context of the studies has changed with the bulk of the recent studies conducted in China or other emerging economies. This change in context also responds to a change in the way these

Table 3

General overview of articles' content.

\begin{tabular}{|c|c|}
\hline $\begin{array}{l}\text { Knowledge, Innovation } \\
\text { and Technology Processes }\end{array}$ & Main concepts \\
\hline External Transfer & $\begin{array}{l}\text { Country } \\
\text { - National Systems of Innovation (Chakrabarti, Feinman, \& Fuentivilla, 1982) } \\
\text { - Countries' Institutional Development (Hendryx, 1986; McGaughey et al., 2000; Tihanyi \& Roath, 2002) } \\
\text { - Regional integration (Tihanyi \& Roath, 2002) } \\
\text { - Host country cultural factors (Buckley et al., 2006; Hendryx, 1986) } \\
\text { Industry } \\
\text { - Inter and Intra-industry relationships (Liu \& Zou, 2008) } \\
\text { Firm } \\
\text { - Firms' property rights protection (McGaughey et al., 2000; Tihanyi \& Roath, 2002) } \\
\text { - Technology FDI and spillovers (Liu \& Zou, 2008) } \\
\text { - International Joint Ventures (Berdrow \& Lane, 2003; Buckley et al., 2006; Osborn \& Baughn, 1987) } \\
\text { - Modes of technology transfer (Liu \& Zou, 2008; Osborn \& Baughn, 1987; Tihanyi \& Roath, 2002) }\end{array}$ \\
\hline Sourcing & $\begin{array}{l}\text { Country } \\
\text { - External embeddedness (Gassmann \& Keupp, 2007) } \\
\text { - Cultural factors affecting technology or innovation sourcing (Zhou, 2007) } \\
\text { Firm } \\
\text { - Knowledge or Technology acquisition mode (Killing, 1980) } \\
\text { - Firms' entrepreneurial orientation (Zhou, 2007) } \\
\text { - Firms' internationalization process (Casillas et al., 2009; Gassmann \& Keupp, 2007; Nordman \& Melén, 2008; Zhou, 2007) } \\
\text { - Domestic vs foreign sourcing (Kafouros \& Forsans, 2012) } \\
\text { Individual } \\
\text { - Managerial - expatriate roles (Kotabe et al., 2011; Li \& Scullion, 2010) } \\
\text { Asset } \\
\text { - Knowledge, innovation or technology characteristics (Li \& Scullion, 2010; Nordman \& Melén, 2008; Zhou, 2007) } \\
\text { - Type of sources of knowledge (Casillas et al., 2009; Kotabe et al., 2011; Li \& Scullion, 2010) }\end{array}$ \\
\hline Internal Transfer & $\begin{array}{l}\text { Country } \\
\text { - Host country environmental factors (Cui et al., 2006; Rugman \& Bennett, 1982) } \\
\text { - Knowledge flows from Headquarters to Subsidiaries (Fang, Wade, Delios, \& Beamish, 2013; Michailova \& Mustaffa, 2012; } \\
\text { Wang et al., 2004) } \\
\text { - Reverse knowledge flows (Asakawa \& Lehrer, 2003; Lazarova \& Tarique, 2005; Michailova \& Mustaffa, 2012; Najafi, Giroud, \& } \\
\text { Andersson, 2014; Rabbiosi \& Santangelo, 2013) } \\
\text { - Transfer mechanisms (Lagerström \& Andersson, 2003; Rabbiosi \& Santangelo, 2013) } \\
\text { Unit } \\
\text { - Subsidiary influence/roles (Asakawa \& Lehrer, 2003; Ciabuschi, Dellestrand, \& Kappen, 2012; Najafi et al., 2014; } \\
\text { Rugman \& Bennett, 1982) } \\
\text { - Subsidiaries performance (Cui et al., 2006; Fang et al., 2013) } \\
\text { - Embeddedness (Najafi et al., 2014) } \\
\text { Team - Individual } \\
\text { - Transnational teams (Lagerström \& Andersson, 2003; Raab et al., 2014) } \\
\text { - Expatriate role and career (Lazarova \& Tarique, 2005) } \\
\text { - Managers' knowledge mobilization (Raab et al., 2014; Tippmann et al., 2014) }\end{array}$ \\
\hline Integration & $\begin{array}{l}\text { Unit } \\
\text { - Compatibility between knowledge's bases (Casillas et al., 2009) } \\
\text { - Realized absorptive capacity (Casillas et al., 2009; Kotabe et al., 2011) } \\
\text { - Level of knowledge acquisition (Kotabe et al., 2011) } \\
\text { Team - Individual } \\
\text { - Social and work interaction (Lagerström \& Andersson, 2003) } \\
\text { - Managers' visionary leadership (Elenkov \& Manev, 2009) } \\
\text { - Cultural intelligence (Elenkov \& Manev, 2009) }\end{array}$ \\
\hline
\end{tabular}


countries have been conceptualized - from passive receivers of FDI spillovers to significant pools of knowledge and innovation that can leverage firm's capabilities.

In the following we will outline the main insights of the four knowledge sub-processes derived from the 30 listed JWB-articles (in Table 3).

\subsubsection{External transfer}

External transfer refers to those processes where firms share their knowledge, innovation and technology across firm boundaries (Eisenhardt \& Santos, 2001). In the case of international firms, external transfer can involve other firms - as it has been in research on for example international joint ventures (IJVs) - but also the host country institutions as well as the nature and quality of innovation in the host country.

In this sense, the quality of the host country environment in terms of its institutional system and property rights protection has been a major theme since the sixties, where some authors analyzed how these factors affected firms' investments abroad (Hendryx, 1986; McGaughey, Liesch, \& Poulson, 2000). The increasing amounts of FDI flows from advanced countries MNEs to emerging or transition economies raised important questions for firms and scholars. For instance, Tihanyi and Roath (2002) pointed at two main factors affecting the institutional development of a country: its market development from planned economies toward the creation of a market driven system and its regional integration with other countries. Taking into account these variables the authors proposed a contingent approach and established different strategies for firms' technology transfer that comprised the technology transfer mode, the technology life cycle and the compensation system. Such a perspective was in accordance with how the IB field developed during the eighties and nineties, where the state of National Systems of Innovation and the FDI spillovers were relevant issues for firms' international strategies (Dunning, 1993; Pearce, 1989). However, more recent contributions evaluate the effect of international foreign spillovers from the emerging countries perspective. Along this line, Liu and Zou (2008) have shown the positive impact that technology-oriented FDI has had on the innovation activities of Chinese firms and have delved into the intra- and inter-industry spillovers generated contingent on the entry mode used, e.g. exports, greenfield or M\&A.

The choice of the technology transfer mode has also been a relevant theme. Initial studies focused on the factors affecting the choice of the type of agreement and the reasons behind the use of licenses or joint ventures (Osborn \& Baughn, 1987). More recently, different authors have advanced our understanding of the IJVs as strategies for technology or knowledge transfer among firms. Through a qualitative study of eight IJVs Berdrow and Lane (2003) identified six dimensions that differentiate the successful ones (e.g. the strategic integration of the IJV activities or the type of mindset of the partners). Applying a learning perspective to joint ventures these authors added relevant insights to extant knowledge (Inkpen, 1995), as they detailed how these six dimensions had a role in both directions of knowledge flows -from the parents to the IJV and also from the IJV to the parents.

The IJVs have also been the context for investigating the relevant question of cultural differences and how they affect the process of external transfer. Buckley, Clegg, and Tan (2006) contributed to the analysis of emerging economies and their specificities by scrutinizing how the importance of networks (guanxi) and face-related issues (mianzi) in China affected the development of relationships with employees, partners and institutions. Part of a fruitful conversation about how cultural differences influenced IB (Shenkar, 2001), their article offered a normative model indicating how cultural awareness improved partners' relationships and knowledge transfer.

\subsubsection{Sourcing}

According to Eisenhardt and Santos (2001) sourcing is the process by which managers identify and gain access to relevant knowledge that is created in the environment i.e. outside the boundaries of the focal firm. This is external sourcing of knowledge that typically will be more competence-creating in nature, when combined with the internal knowledge. Recognition and access are two components of sourcing that imply different capabilities from managers. While the recognition of the knowledge gaps is a process that depends mainly on the managers learning and assessment capabilities (Petersen, Pedersen, \& Lyles, 2008), the access to relevant knowledge is more dependent on firms and managers tapping into specialized knowledge through network embeddedness (Andersson, Forsgren, \& Holm, 2002). In addition, a recent stream of research explores the heterogeneity in MNEs abilities to achieve embeddedness in knowledge clusters (Cantwell \& Mudambi, 2011). This research concludes that leading MNEs are much more likely to achieve the "insider" status in local knowledge networks that is a key requirement for knowledge sourcing (Giuliani, 2007). In contrast, lagging MNEs remain "outsiders" and are forced to rely on their parent's knowledge resources.

Along these years the JWB has considered different issues related to knowledge and technology sourcing processes. Probably, the most relevant contributions have been related to the role of knowledge as a source for firms' internationalization processes. The special issue launched in 2007 about the early and rapid internationalization of the firm contributed strongly to the substantial debate about the role that experiential knowledge (Eriksson, Johanson, Majkgard, \& Sharma, 1997) and international entrepreneurial orientation (Knight \& Cavusgil, 2004) play in the internationalization process of the firm (Johanson \& Vahlne, 1977; Oviatt \& McDougall, 1994). Zhou (2007) tested both factors on young international firms in China and found a separate effect of three dimensions of entrepreneurial orientation, where the proactiveness dimension were the most relevant for obtaining foreign market knowledge.

Gassmann and Keupp (2007) applied a knowledge-based view and identified several factors contributing to the competitive advantage of born global SMEs. Among them, the firms' embeddedness in global communities and networks was pointed out as the one that allowed them to update and maintain their specialized knowledge at low marginal cost, which constituted part of the competitive advantage of born global SMEs. Hence, Gassmann and Keupp (2007) extended to SMEs some of the arguments that previously were pointed out as critical in the context of subsidiaries' competence development (Andersson et al., 2002; Andersson, Forsgren, \& Holm, 2007). Casillas, Moreno, Acedo, Gallego, and Ramos (2009) proposed that in the context of knowledge needed for entry into a new market, external sources of information are absorbed more slowly by the firm than its own internal sources, since the latter depend on its own current experiences and knowledge.

Not only has the origin of the knowledge been analyzed in relation to firms' internationalization processes, but also the type of knowledge managers and founders possess - international knowledge and technological knowledge (Nordman \& Melén, 2008). Interestingly, this type of knowledge matters for the way firms' managers discover new foreign market opportunities and commit to them. All in all, these studies contributed to the extensive conversation on the proactive or reactive character of firms' internationalization processes (Forsgren, 2002; Petersen, Pedersen, \& Sharma, 2003; Johanson \& Vahlne, 2009).

The role of managers in providing knowledge has been recently emphasized. Both Li and Scullion (2010) and Kotabe, Jiang, and Murray (2011) identify the importance of managerial ties as well as 
political and business ties to facilitate external knowledge acquisition, in particular, in the case of firms operating in emerging markets where the nature of local knowledge is different in terms of tacitness and diffusion. Adopting a micro-foundations perspective, Tippmann, Scott, and Mangematin (2014) qualitative study provides rich findings about the different practices and patterns that subsidiaries' managers follow for sourcing knowledge. According to their study, such practices differ depending on the type of problem that managers face. While deliberate knowledge flows (e.g. top-down knowledge inflows) occur mostly within functional domains and serve for routine problems, when managers face non-routine problems and search for specifics solutions, they promote emergent knowledge inflows. Such types of inflows aim at pursuing boundary-spanning knowledge mobilizations and are mainly bottom-up and lateral knowledge flows that increase the potential to develop creative and innovative solutions to non-routine problems.

While the initial focus was more aggregate with articles providing attention on how firms could source technology by using different technology modes (Killing, 1980) the most recent articles in JWB have extended our understanding of the sourcing processes by adding knowledge on the explanatory mechanisms at the micro levels that helps understand the role of the individual in catalyzing this knowledge process.

\subsubsection{Internal transfer}

Internal transfer processes are related to the sharing of knowledge, innovation and technology within firms' boundaries. Regarding to this type of processes, IB literature has been greatly influenced by the Knowledge-Based View (KBV) (Grant, 1996; Kogut \& Zander, 1993) as well as by Gupta and Govindarajan (2000) analysis of MNEs internal knowledge flows.

For instance, Wang, Tong, and Koh (2004) analyzed the factors affecting knowledge transfer from MNEs' headquarters to their Chinese subsidiaries taking into account two kinds of factors, the capacity and willingness of the MNE for transferring knowledge and the capacity and intent to learn by the subsidiary. Even though their analysis was at the subsidiary level, the recognition of the dual effect of willingness and ability was in line with some of the seminal studies at this time period pin-pointing the need to uncover the micro-foundations of knowledge transfer processes (Minbaeva, Pedersen, Björkman, Fey, \& Park, 2003; Foss \& Pedersen, 2004).

The debate about the knowledge flows and the factors that intervene in realizing knowledge transfer has been one of the most fruitful in IB literature. Along these lines, Michailova and Mustaffa (2012) made an insightful contribution by reviewing the IB literature and categorizing the main factors affecting subsidiary knowledge flows. Their study provides a clear picture on the main issues analyzed during the two last decades and gives relevant guidelines for future research. We will return to some of them in the next section.

Knowledge and high value-added activities have been recognized as critical for subsidiaries specific advantages (Rugman \& Verbeke, 2001) and for subsidiary power (Mudambi \& Navarra, 2004; Mudambi et al., 2014). One of the earliest contributions on subsidiary roles was conducted by Rugman and Bennett (1982), whose article about the technology transfer through world product mandate preceded the wave of research about MNEs internal configuration (Bartlett \& Ghoshal, 1989; Hedlund, 1986) and discussed a more active role of the parent in assigning mandates to subsidiaries where strategic issues rather than local government subsidies were taken into account.

As in the case of external transfer, internal transfer in MNEs is also affected by environmental factors. Cui, Griffith, Cavusgil, and Dabic (2006) made a joint analysis of several environmental factors that affected subsidiaries adoption of transferred technology and showed that both market factors and cultural factors related to the host country matters for internal knowledge transfer. Particularly market dynamism and organizational cultural distance came forth as the factors with the strongest effect. As Michailova and Mustaffa (2012) point out in their literature review, subsidiaries have been studied more as receivers than senders of knowledge flows, which create space for future research on the direction of knowledge flows within the MNE and how to manage them.

Along this line, there have been several contributions in JWB on the "reverse knowledge transfer" or process where the knowledge or the innovations flow from the foreign units toward the center of the MNE. Taking into account the interactions between the subsidiaries and their geographical locations, Asakawa and Lehrer (2003) provided important insights about the role that regional offices can play as innovation relays that linked local knowledge to the MNE's global operations. In addition they identified the patterns followed by those MNEs that had dispersed innovation processes. On a more micro viewpoint, Lazarova and Tarique (2005) focused on repatriates as knowledge recipients and the types of knowledge they acquire depending on the type of assignment they have performed abroad. In order to improve the reverse knowledge transfer, the authors suggested firms should strive for a fit between the career development initiatives offered and the repatriate career goals. Recently, Najafi, Giroud, and Andersson (2014), studied the role of reverse knowledge transfer for subsidiary influence in MNEs looking at the interplay between network activities and knowledge actions.

\subsubsection{Integration}

Integration processes consist of combining knowledge from different sources to generate new knowledge or to applying it for innovation (Eisenhardt \& Santos, 2001). Research on knowledge integration processes has focused on constructs at a more micro level of analysis, applying some of the insights from the organizational learning literature (Cohen \& Levinthal, 1990; Zahra \& George, 2002). Both Casillas et al. (2009) and Kotabe et al. (2011) apply the concepts realized absorptive capacity and compatibility between knowledge bases.

Other studies have investigated factors that can promote knowledge integration and the mechanisms firms can deploy to promote knowledge processes. Lagerström and Andersson (2003) study the case of transnational teams and found that going beyond information technology and creating organizational structures supporting employees' interaction improved efficient communication. Additionally, their qualitative study pointed at the proficiency in a common business language as a key factor for knowledge sharing and creation. In this regard, their work was novel as it signaled that one factor - language differences - was of outmost importance, which nowadays is considered critical for well-functioning internal knowledge transfer processes (Mäkelä, Andersson, \& Seppälä, 2012; Tenzer, Pudelko, \& Harzing, 2014).

Individual characteristics have also been analyzed as relevant factors affecting integration processes. For instance, Elenkov and Manev (2009) show that a visionary-transformational leadership style of expatriates positively influenced innovation levels in the units. Further their study shows that the expatriates' cultural intelligence is a factor that positively moderates this effect.

\section{Discussion}

The foregoing analysis has highlighted the central role played by the Journal of World Business in developing the agenda in international dimensions of technology, innovation and knowledge research. Beginning with the influential Killing (1980) study through more recent significant works like in areas like emerging 
markets (Cui et al., 2006) and green strategies (Eiadat, Kelly, Roche, \& Eyadat, 2008), JWB has consistently published key articles that have often opened up new research streams. Along with this consistency in high quality path-breaking research, we also find some systematic changes.

We find that in earlier decades, the predominant focus of study was at the level of 'technology'. In more recent decades, the focus has shifted to the wider level of 'innovation', while in the last decade it has grown even wider, with an emphasis on 'knowledge'. Our meta-analysis supports the view that this change in semantics reflects a deeper shift toward a wider research lens in this domain of international business research.

Allied with this widening of research focus, we note a drift in the unit of analysis to a more disaggregated level. While early work was largely conducted at the country and industry level, it later moved on to the firm level and sometimes even to the team or the individual level. In the most recent decade, a great deal of the research has been conducted at the intra-MNE level, allowing for the extrication of underlying mechanisms in knowledge processes as the more complex interaction between firms and locations for knowledge accessing and diffusion or the relevance of the individual (e.g. managers, expatriates, employees, etc.) for driving connectivity within and across firms. Out of the focused 34 papers the majority (27 papers) are empirical papers (almost $80 \%$ ), but only six papers take the individual level into account. The first of these six papers was published in 2009 which shows that dealing with the individual level is a fairly recent phenomenon in studies on innovation, technology, and knowledge. Only one single paper (Raab, Ambos, \& Tallman, 2014) applies a multi-level approach that includes the individual level.

We hasten to emphasize that JWB is not unique in this regard. Our robustness test on papers in JIBS supports our finding. Within IB research there appears to be growing recognition that (a) the exploration for new sources of value creation is a generic strategy that is served by technology, innovation and knowledge creation; and (b) that exploration processes tend to vary dramatically within firms and even across projects within firm subunits (Andersson, Gaur, Mudambi, \& Persson, 2015).

While this progress of the literature is to be lauded, we note a corresponding lack of studies that integrate the various levels of analysis. With some exceptions (Lederman, 2010; Raab et al., 2014), the most recent studies typically undertake careful disaggregation and provide a detailed analysis of knowledge processes at a very high level of granularity. While such studies answer the call for building knowledge processes up from their microfoundations, it is equally true that collective level of analysis is more than simple aggregations of their constituent individuals and subunits. As recognized explicitly by evolutionary theorists beginning with Nelson and Winter (1982), the routines that form the basis of organizational capabilities are structurally embedded and cannot be imitated merely by assembling a similar set of resources. However, knowledge is a multilevel construct: knowledge resides within the minds of individuals and is absorbed and transferred by individuals, while synergies and interactions are manifested at the organizational level. Hence a complete understanding of knowledge processes requires an integration of the individual level of analysis with more aggregate levels. Such a research program requires the use of a multilevel approach (Andersson, Cuervo-Cazurra, \& Nielsen, 2014) that requires the recognition that the objectives of lower levels of analysis like individuals and teams overlap only partly with those of higher levels of analysis (Nohria \& Ghoshal, 1994; Mudambi \& Navarra, 2004; Andersson et al., 2007).

While this is a critical analytical method, it is only one among many approaches to disaggregating and analyzing knowledge processes. In addition to hierarchical disaggregation, knowledge processes can be disaggregated along functional lines. Knowledge integration often requires the application of diverse skills sets that reside in specialized professional communities, e.g., scientists working with managers or R\&D units working with marketing units (Mudambi et al., 2014). This form of aggregation requires applying boundary-spanning theory (Carlile, 2002) to knowledge processes in the international setting (Schotter \& Beamish, 2010). How individual knowledge that is structured within a specific function can be combined with other functional knowledge? How individuals interact within higher-level units for establishing links and for managing other interactions with the external environment? To what extent the effectiveness of connectivity, in terms of managing knowledge processes, is affected by both individuallevel characteristics and higher-level determinants, such as team leadership or HR practices? Boundary-spanning literature (Ancona \& Caldwell, 1992; Carlile, 2002; Marrone, 2010) can provide a propitious lens for analyzing how MNEs manage knowledgerelated processes as it helps understand the challenges raised by boundaries (not only geographic but also organizational) and complexity.

The most promising avenues for future research are at the intersection of these two nexuses. Recognizing that both multiple levels of analysis as well as diversity are inherent in knowledge processes is crucial, especially as competitive pressures increase with new, aggressive competitors from emerging markets. Knowledge-based competition is occurring in an increasingly global arena, resulting in faster technology cycles. Value is rapidly migrating out of tangible goods to intangibles (Mudambi, 2008) that are heavily reliant on tacit knowledge elements like design (Scalera, Mukherjee, Perri, \& Mudambi, 2014). This rising complexity means that single level and uni-dimensional studies become progressively poorer approximations of reality. Future researchers face great challenges, but have at their disposal analytical theories and methods with enormous promise.

\section{References}

Alavi, M., \& Leidner, D. E. (2001). Review: Knowledge management and knowledge management systems: Conceptual foundations and research issues. MIS Quarterly, 25(1): 107-136.

Ancona, D. G., \& Caldwell, D. F. (1992). Bridging the boundary: External activity and performance in organizational teams. Administrative Science Quarterly, 37: 634665.

Andersson, U., Cuervo-Cazurra, A., \& Nielsen, B. (2014). Explaining interaction effects within and across levels of analysis. Journal of International Business Studies, 45: 1063-1071.

Andersson, U., Forsgren, M., \& Holm, U. (2002). The strategic impact of external networks - Subsidiary performance and competence development in the multinational corporation. Strategic Management Journal, 23(11): 979-996.

Andersson, U., Forsgren, M., \& Holm, U. (2007). Balancing subsidiary influence in the federative MNC - A business network perspective. Journal of International Business Studies, 38(5): 802-818.

Andersson, U., Gaur, A., Mudambi, R., \& Persson, M. (2015). Unpacking inter-unit knowledge transfer in MNCs. Global Strategy Journal, 5(3): 241-255.

Asakawa, K., \& Lehrer, M. (2003). Managing local knowledge assets globally: The role of regional innovation relays. Journal of World Business, 38: 31-42.

Bartell, M. (1984). *Innovation and the Canadian experience: A perspective. Columbia Journal of World Business, 19(4): 88.

Bartlett, C., \& Ghoshal, S. (1989). Managing across borders. The transnational solution. Boston: Harvard Business School Press.

Berdrow, I., \& Lane, H. W. (2003). International joint ventures: Creating value through successful knowledge management. Journal of World Business, 38: 1530.

Bojica, A. M., \& Fuentes, M. M. F. (2012). *Knowledge acquisition and corporate entrepreneurship: Insights from Spanish SMEs in the ICT sector. Journal of World Business, 47(3): 397.

Borlaug, N. E. (1969). *A green revolution yields a golden harvest: Technology can be more revolutionary than any "ism"; agricultural, more than industrial, technology is transforming the internal economies of developing countries and may soon be a source of critically needed foreign exchange. Columbia Journal of World Business, 4: 9-19.

Bouquet, C., \& Birkinshaw, J. (2008). Weight versus voice: How foreign subsidiaries gain attention from corporate headquarters. Academy of Management Journal, 51(3): 577-601 
Buckley, P. J., \& Casson, M. (1976). The future of multinational enterprise. London: Macmillan.

Buckley, P. J., Clegg, J., \& Tan, H. (2006). Cultural awareness in knowledge transfer to China. The role of guanxi and mianzi. Journal of World Business, 41: 275-288.

Camillus, J. C. (1984). *Technology-driven and market-driven life cycles: Implications for multinational corporate strategy. Columbia Journal of World Business, 19(2): 56.

Cantwell, J., \& Mudambi, R. (2005). MNE competence-creating subsidiary mandates. Strategic Management Journal, 26(12): 1109-1128.

Cantwell, J., \& Mudambi, R. (2011). Physical attraction and the geography of knowledge sourcing in multinational enterprises. Global Strategy Journal, 1(34): 206-232.

Carlile, P. (2002). A pragmatic view of knowledge and boundaries: Boundary objects in new product development. Organization Science, 13(4): 442-455.

Casillas, J. C., Moreno, A. M., Acedo, F. J., Gallego, M. A., \& Ramos, E. (2009). An integrative model of the role of knowledge in the internationalization process. Journal of World Business, 44: 311-322.

Chakrabarti, A. K., Feinman, S., \& Fuentivilla, W. (1982). The cross-national comparison of patterns of industrial innovations. Columbia Journal of World Business, 17: 33-40.

Chari, M. D. R., Devaraj, S., \& David, P. (2007). *International diversification and firm performance: Role of information technology investments. Journal of World Business, 42(2): 184-197.

Chen, C., \& Hsiao, Y. (2013). *The endogenous role of location choice in product innovations. Journal of World Business, 48(3): 360-372.

Chorafas, D. N. (1970). *Computer technology in western and Eastern Europe. Columbia Journal of World Business, 5: 61-66.

Ciabuschi, F., Dellestrand, H., \& Kappen, P. (2012). The good, the bad, and the ugly: Technology transfer competence, rent-seeking, and bargaining. Journal of World Business, 47: 664-673.

Cohen, W. M., \& Levinthal, D. A. (1990). Absorptive capacity: A new perspective on learning and innovation. Administrative Science Quarterly, 35: 128-152.

Contractor, F. J. (1983). *Technology licensing practice in US companies: Corporate and public policy implications. Columbia Journal of World Business, 18: 80-88.

Contractor, F., Kumar, V., Kundu, S., \& Pedersen, T. (2010). Reconceptualizing the firm in a world of outsourcing and offshoring: The organizational and geographical relocation of high-value company functions. Journal of Management Studies, 47(8): 1417-1433.

Cui, A. S., Griffith, D. A., Cavusgil, S. T., \& Dabic, M. (2006). The influence of market and cultural environmental factors on technology transfer between foreign MNCs and local subsidiaries: A Croatian illustration. Journal of World Business, 41: $100-111$

Daneke, G. A. (1984). *The global contest over the control of the innovation process: The case of biotech. Columbia Journal of World Business, 19(4): 83.

Drazin, R. (1984). *Worldwide industrial innovation. Columbia Journal of World Business, 19: 5-29.

Dunning, J. H. (1993). Multinational enterprise and the global economy. Reading, MA: Addison-Wesley.

Eiadat, Y., Kelly, A., Roche, F., \& Eyadat, H. (2008). Green and competitive? An empirical test of the mediating role of environmental innovation strategy. Journal of World Business, 43(2): 131-145.

Eisenhardt, K. M., \& Santos, F. M. (2001). Knowledge-based view: A new theory of strategy? In A. Pettigrew, H. Thomas, \& R. Whittington (Eds.), Handbook of strategy and management. Sage Publications.

Elenkov, D. S., \& Manev, I. M. (2009). Senior expatriate leadership's effects on innovation and the role of cultural intelligence. Journal of World Business, 44: 357-369.

Eriksson, K., Johanson, J., Majkgard, A., \& Sharma, D. D. (1997). Experiential knowledge and cost in the internationalization process. Journal of International Business Studies, 28(2): 337-360.

Evangelista, F., \& Hau, L. N. (2009). *Organizational context and knowledge acquisition in IJVs: An empirical study. Journal of World Business, 44(1): 63-73.

Fang, Y., Wade, M., Delios, A., \& Beamish, P. (2013). An exploration of multinational enterprise knowledge resources and foreign subsidiary performance. Journal of World Business, 48: 30-38.

Ferdows, K., \& Rosenbloom, R. S. (1981). *Technology policy and economic development: Perspectives for Asia in the 1980s. Columbia Journal of World Business, 16(2): 36.

Forsgren, M. (2002). The concept of learning in the Uppsala internationalization process model: A critical review. International Business Review, 11: 257-277.

Foss, N. J., \& Pedersen, T. (2004). Organizing knowledge processes in the multinational corporation: An introduction. Journal of International Business Studies, 35: 340-346.

Gassmann, O., \& Keupp, M. M. (2007). The competitive advantage of early and rapidly internationalizing SMEs in the biotechnology industry: A knowledgebased view. Journal of World Business, 42: 350-366.

Giuliani, E. (2007). The selective nature of knowledge networks in clusters: Evidence from the wine industry. Journal of Economic Geography, 7(2): 139-168.

Globerman, S., \& Meredith, L. (1984). *The foreign ownership-innovation nexus in Canada. Columbia Journal of World Business, 19(4): 53.

Grant, R. (1996). Toward a knowledge-based theory of the firm. Strategic Management Journal, 17: 109-122.

Gupta, A. K., \& Govindarajan, V. (2000). Knowledge flows within multinational corporations. Strategic Management Journal, 21(4): 473-496.

Hayden, E., \& Nau, H. (1975). *East-west technology transfer - Theoretical models and practical experiences. Columbia Journal of World Business, 10(3): 70
Hedlund, G. (1986). The hypermodern MNC. A heterarchy? Human Resource Management, 25: 9-35.

Hendryx, S. R. (1986). Implementation of a technology transfer joint venture in the People's Republic of China: A management perspective. Columbia Journal of World Business, 21: 57-66.

Hill, J. S., \& Still, R. R. (1980). *Cultural effects of technology transfer by multinational corporations in lesser developed countries. Columbia Journal of World Business, 15(2): 40

Hong, J. F. L., \& Nguyen, T. V. (2009). *Knowledge embeddedness and the transfer mechanisms in multinational corporations. Journal of World Business, 44(4): 347-356.

Husted, K., \& Vintergaard, C. (2004). *Stimulating innovation through corporate venture bases. Journal of World Business, 39(3): 296-306.

Hyman, R., Treeck, W., \& Sockell, D. (1989). *New technology and industrial relations. Columbia Journal of World Business, 24(4): 79.

Inkpen, A. C. (1995). Organizational learning and international joint ventures. Journal of International Management., 1(2): 165-198.

Johanson, J., \& Vahlne, J. E. (1977). The internationalization process of the firm: A model of knowledge development and increasing foreign market commitments. Journal of International Business Studies, 8: 23-32.

Johanson, J., \& Vahlne, J. E. (2009). The Uppsala internationalization process model revisited: From liability of foreignness to liability of outsidership. Journal of International Business Studies, 40: 1411-1431.

Kafouros, M. I., \& Forsans, N. (2012). The role of open innovation in emerging economies: Do companies profit from the scientific knowledge of others? Journal of World Business, 47: 362-370.

Kaufmann, L., \& Reossing, S. (2005). *Managing conflict of interests between headquarters and their subsidiaries regarding technology transfer to emerging markets - a framework. Journal of World Business, 40(3): 235-253.

Killing, J. P. (1980). Technology acquisition: License agreement or joint venture. Columbia Journal of World Business, 15: 38-46.

King, W. R. (1985). *Information technology and corporate growth. Columbia Journal of World Business, 20(2): 29.

Klavans, R., Shanley, M., \& Evan, W. M. (1985). *The management of internal corporate ventures: Entrepreneurship and innovation. Columbia Journal of World Business, 20(2): 21

Klitmøller, A., \& Lauring, J. (2013). *When global virtual teams share knowledge: Media richness, cultural difference and language commonality. Journal of World Business, 48(3): 398.

Knight, G. A., \& Cavusgil, S. T. (2004). Innovation, organization capabilities and the born-global firm. Journal of International Business Studies, 35: 124141.

Kogut, B., \& Zander, U. (1993). Knowledge of the firm and the evolutionary theory of the multinational corporation. Journal of International Business Studies, 24(4): 625-645.

Kotabe, M., Jiang, C. X., \& Murray, J. Y. (2011). Managerial ties, knowledge acquisition, realized absorptive capacity and new market performance of emerging multinational companies: A case of China. Journal of World Business, 46: $166-176$.

Krishna, E. M., \& Rao, C. P. (1986). *Is US high technology high enough? Columbia Journal of World Business, 21(2): 47.

Kuemmerle, W. (1999). The drivers of foreign direct investment into research and development: An empirical investigation. Journal of International Business Studies, 30(1): 1-24.

Laforet, S. (2013). *Organizational innovation outcomes in SMEs: Effects of age, size, and sector. Journal of World Business, 48(4): 490.

Lagerström, K., \& Andersson, M. (2003). Creating and sharing knowledge within a transnational team: The developments of a global business system. Journal of Word Business, 38: 84-95.

Lazarova, M., \& Tarique, I. (2005). Knowledge transfer upon repatriation. Journal of World Business, 40: 361-373.

Lederman, D. (2010). An international multilevel analysis of product innovation. Journal of International Business Studies, 41: 606-619.

Lee, S., Trimi, S., \& Kim, C. (2013). *The impact of cultural differences on technology adoption. Journal of World Business, 48(1): 20-29.

Lehrer, M., \& Asakawa, K. (2002). *Offshore knowledge incubation: The "third path" for embedding R\&D labs in foreign systems of innovation. Journal of World Business, 37(4): 297-306.

Li, S., \& Scullion, H. (2010). Developing the local competence of expatriate managers for emerging markets: A knowledge-based approach. Journal of World Business, 45: 190-196.

Liao, T., \& Yu, C. J. (2012). *Knowledge transfer, regulatory support, legitimacy, and financial performance: The case of foreign firms investing in China. Journal of World Business, 47(1): 114-122.

Liu, X., \& Zou, H. (2008). The impact of greenfield FDI and mergers and acquisitions on innovation in Chinese high-tech industries. Journal of World Business, 43: 352-364.

Lorenzen, M., \& Mudambi, R. (2013). Clusters, connectivity and catch-up: Bangalore and Bollywood in the global economy. Journal of Economic Geography, 13(3): 501-534.

Lovett, S., Coyle, T., \& Adams, R. (2004). *Job satisfaction and technology in Mexico. Journal of World Business, 39(3): 217-232.

Lundvall, B. Å. (2007). National innovation systems-Analytical concept and development tool. Industry and Innovation, 14(1): 95-119.

Luthans, F., \& Slocum, J. W. (1997). The Journal of World Business in launched. Editor's note. Journal of World Business, 32(1): 1-2. 
Luthans, F., \& Slocum, J. W. (2000). Editor's note. Journal of World Business, 35(4): $331-332$.

Lynn, L. (1984). *Japan adopts a new technology: The roles of government, trading firms and suppliers. Columbia Journal of World Business, 19(4): 39.

Marrone, J. A. (2010). Team boundary spanning. A multilevel review of past research and proposals for the future. Journal of Management., 36: 911-940.

Martyn, H. (1969). *I spy: The theft of knowledge is today a business as multinational in its drive and structure as any corporate entity. Columbia Journal of World Business, 4: 47-56.

McGaughey, S. L., Liesch, P. W., \& Poulson, D. (2000). An unconventional approach to intellectual property protection: The case of an Australian firm transferring shipbuilding technologies to China. Journal of World Business, 35: 1-20.

Michailova, S., \& Mustaffa, Z. (2012). Subsidiary knowledge flow in multinational corporations: Research accomplishments, gaps, and opportunities. Journal of World Business, 47: 383-396.

Minbaeva, D. B., Pedersen, T., Björkman, I., Fey, C. F., \& Park, H. J. (2003). MNC knowledge transfer, subsidiary absorptive capacity and HRM. Journal of International Business Studies, 34: 586-599.

Morck, R., \& Yeung, B. (1991). Why do investors value multinationality? Journal of Business, 64(2): 165-187.

Mudambi, R., \& Navarra, P. (2004). Is knowledge power? Knowledge flows, subsidiary power and rent seeking within MNCs. Journal of International Business Studies, 35(5): 385-406.

Mudambi, R. (2008). Location, control and innovation in knowledge intensive industries. Journal of Economic Geography, 8(5): 699-725.

Mudambi, R., Pedersen, T., \& Andersson, U. (2014). How subsidiaries gain power in multinational corporations. Journal of World Business, 49: 101-113.

Mäkelä, K., Andersson, U., \& Seppälä, T. (2012). Interpersonal similarity and knowledge sharing within multinational organizations. International Business Review, 21: 439-451.

Najafi, Z., Giroud, A., \& Andersson, U. (2014). The interplay of networking activities and internal knowledge actions for subsidiary influence within MNCs. Journal of World Business, 49(1): 122-131.

Nelson, R., \& Winter, S. (1982). An evolutionary theory of economic change. Cambridge, MA: Harvard University Press.

Nohria, N., \& Ghoshal, S. (1994). Differentiated fit and shared values: Alternatives for managing headquarters-subsidiary relations. Strategic Management Journal, 15(6): 491-502.

Nordman, E. R., \& Melén, S. (2008). The impact of different kinds of knowledge for the internationalization process of Born Globals in the biotech business. Journal of World Business, 43: 171-185

Okimoto, D. I., \& Cargill, T. F. (1989). *Between MITI and the market: Japanese industrial policy for high technology. Columbia Journal of World Business, 24(4): 75.

Osborn, R. B., \& Baughn, C. C. (1987). New patterns in the formation of US-Japanese cooperative ventures: The role of technology. Columbia Journal of World Business, 22: 57-66.

Ostry, S. (1990). *Governments \& corporations in a shrinking world: Trade \& innovation policies in the United States, Europe \& Japan. Columbia Journal of World Business, 25(1): 10.

Oviatt, B. M., \& McDougall, P. P. (1994). Toward a theory of international new ventures. Journal of International Business Studies, 25: 45-64.

Ozawa, T. (1971). *Japan exports technology to Asian LDCs: Traditionally an importer of western technology, Japan is beginning to export her own technology to neighboring Asian markets. Columbia Journal of World Business, 6: 65-71.

Ozawa, T. (1972). *Japans' technology now challenges the West. Columbia Journal of World Business, 7(2): 41-49.

Patriotta, G., Castellano, A., \& Wright, M. (2013). *Coordinating knowledge transfer: Global managers as higher-level intermediaries. Journal of World Business, 48(4): 515-525.

Pearce, R. (1989). The internationalization of research and development by multinational enterprises. New York: St Martin's Press.

Petersen, B., Pedersen, T., \& Lyles, M. (2008). Closing knowledge gaps in foreign markets. Journal of International Business Studies, 39: 1097-1113.

Petersen, B., Pedersen, T., \& Sharma, D. D. (2003). Knowledge transfer performance of multinational companies. Management International Review, 43(3): 69-90.

Rabbiosi, L., \& Santangelo, G. D. (2013). Parent company benefits from reverse knowledge transfer: The role of the liability of newness in MNEs. Journal of World Business, 48(1): 160-170.

Rodrigues, C. A. (1985). *A process for innovators in developing countries to implement new technology. Columbia Journal of World Business, 20(3): 21.
Rondinelli, D. A. (1993). *National innovation systems: A comparative analysis. Columbia Journal of World Business, 28(4): 94

Rugman, A., \& Bennett, J. (1982). Technology transfer and world product mandating in Canada. Columbia Journal of World Business, 17: 58-62.

Rugman, A., \& Verbeke, A. (2001). Subsidiary-specific advantages in multinational enterprises. Strategic Management Journal, 22: 237-250.

Raab, K., Ambos, B., \& Tallman, S. (2014). Strong or invisible hands? Managerial involvement in the knowledge sharing process of globally dispersed groups. Journal of World Business, 49: 32-41.

Scalera, V., Mukherjee, D., Perri, A., \& Mudambi, R. (2014). A longitudinal study of MNE innovation: The case of Goodyear. Multinational Business Review, 22(3): 270-293.

Schoonhoven, C. B. (1984). *High technology firms: Where strategy really pays off. Columbia Journal of World Business, 19(4): 5.

Schotter, A., \& Beamish, P. (2010). Performance effects of MNC headquarters Subsidiary conflict and the role of boundary spanners: The case of headquarter initiative rejection. Journal of International Management, 17(3): 243-259.

Shenkar, O. (2001). Cultural distance revisited: Towards a more rigorous conceptualization and measurement of cultural differences. Journal of International Business Studies, 32: 519-536.

Shrivastava, P. (1984). *Technological innovation in developing countries. Columbia Journal of World Business, 19(4): 23.

Simon, E. (1996). *Innovation and intellectual property protection: The software industry perspective. Columbia Journal of World Business, 31(1): 30-37.

Steers, R. M., Meyer, A. D., \& Sanchez-Runde, C. (2008). *National culture and the adoption of new technologies. Journal of World Business, 43(3): 255-260.

Sunaoshi, Y., Kotabe, M., \& Murray, J. Y. (2005). *How technology transfer really occurs on the factory floor: A case of a major Japanese automotive die manufacturer in the United States. Journal of World Business, 40(1): 57-70.

Tang, R. Y. W., \& Tse, E. (1986). *Accounting technology transfer to less developed countries and the Singapore experience. Columbia Journal of World Business, 21(2): 85 .

Tenzer, H., Pudelko, M., \& Harzing, A. W. (2014). The impact of language barriers on trust formation in multinational teams. Journal of International Business Studies, 45: 508-535.

Tian, X. (2010). *Managing FDI technology spillovers: A challenge to TNCs in emerging markets. Journal of World Business, 45(3): 276-284.

Tihanyi, L., \& Roath, A. S. (2002). Technology transfer and institutional development in Central and Easter Europe. Journal of World Business, 37: 188-198.

Ting, W. (1980). *A comparative analysis of the management technology and performance of firms in newly industrializing countries. Columbia Journal of World Business, 15(3): 83.

Tippmann, E., Scott, P. S., \& Mangematin, V. (2014). Subsidiary managers' knowledge mobilizations: Unpacking emergent knowledge flows. Journal of World Business, 49(3): 431.

Tsurumi, Y. (1979). *Two models of corporation and international transfer of technology. Columbia Journal of World Business, 14(2): 43.

Tsurumi, Y. (1982). *Japan's challenge to the U.S.: Industrial policies and corporate strategies challenge to the USA posed by the emergence of "group capitalism" keiretsu, emphasizing global market share and the development of production and institutional technology. Columbia Journal of World Business, 17: 87-95.

Wallender, H. W. (1980). *Developing country orientations toward foreign technology in the eighties: Implications for new negotiation approaches. Columbia Journal of World Business, 15(2): 20.

Wang, P., Tong, T. W., \& Koh, C. P. (2004). An integrated model of knowledge transfer from MNC parent to China subsidiary. Journal of World Business, 39: $168-182$.

Wescott, W. F. (1993). *Environmental technology cooperation: A quid pro quo for transnational corporations and developing countries. Columbia Journal of World Business, 27(3): 144

Wijk, R. V., Jansen, J. J. P., \& Lyles, M. A. (2008). Inter- and intra-organizational knowledge transfer: A meta-analytic review and assessment of its antecedents and consequences. Journal of Management Studies, 45: 830-853.

Williams, C., \& Lee, S. H. (2011). *Entrepreneurial contexts and knowledge coordination within the multinational corporation. Journal of World Business, 46(2): 253-264

Zaheer, S., \& Nachum, L. (2011). Sense of place: From location resources to MNE locational capital. Global Strategy Journal, 1: 96-108.

Zahra, S. A., \& George, G. (2002). Absorptive capacity: A review, reconceptualization and extension. Academy of Management Review, 27: 185-203.

Zhou, L. (2007). The effects of entrepreneurial proclivity and foreign market knowledge on early internationalization. Journal of World Business, 42: 281-293. 